\title{
A novel paradigm for heart failure with preserved ejection fraction
}

Citation for published version (APA):

Cuijpers, I. J. N. M. (2020). A novel paradigm for heart failure with preserved ejection fraction: Working towards understanding the pathology of HFpEF. [Doctoral Thesis, Maastricht University, KU Leuven]. Maastricht University. https://doi.org/10.26481/dis.20201028ic

Document status and date:

Published: 01/01/2020

DOI:

10.26481/dis.20201028ic

Document Version:

Publisher's PDF, also known as Version of record

\section{Please check the document version of this publication:}

- A submitted manuscript is the version of the article upon submission and before peer-review. There can be important differences between the submitted version and the official published version of record.

People interested in the research are advised to contact the author for the final version of the publication, or visit the DOI to the publisher's website.

- The final author version and the galley proof are versions of the publication after peer review.

- The final published version features the final layout of the paper including the volume, issue and page numbers.

Link to publication

\footnotetext{
General rights rights.

- You may freely distribute the URL identifying the publication in the public portal. please follow below link for the End User Agreement:

www.umlib.nl/taverne-license

Take down policy

If you believe that this document breaches copyright please contact us at:

repository@maastrichtuniversity.nl

providing details and we will investigate your claim.
}

Copyright and moral rights for the publications made accessible in the public portal are retained by the authors and/or other copyright owners and it is a condition of accessing publications that users recognise and abide by the legal requirements associated with these

- Users may download and print one copy of any publication from the public portal for the purpose of private study or research.

- You may not further distribute the material or use it for any profit-making activity or commercial gain

If the publication is distributed under the terms of Article $25 \mathrm{fa}$ of the Dutch Copyright Act, indicated by the "Taverne" license above, 


\section{English Summary}

More than half of the patients with heart failure (HF) suffer from heart failure with preserved ejection fraction (HFpEF; ejection fraction $>50 \%$ ), a complex cardiovascular syndrome characterised by diastolic dysfunction and cardiac stiffening, fibrosis, inflammation, and hypertrophy. Due to the ageing population, as well as increased incidence of common comorbidities, such as type 2 diabetes mellitus, hypertension, and obesity, the prevalence of HFpEF is increasing dramatically. Alarmingly, there are no specific evidence-based therapies for $\mathrm{HFpEF}$, likely due to the incomplete understanding of the pathology, heterogeneity in the patient population, and inadequate diagnosis. In this thesis, we therefore investigated the disease progression and established early characteristics of HFpEF in the obese ZSF1 rat, which mimics human pathology. This will facilitate risk stratification and the development of prevention and treatment strategies.

Chapter 1 introduces the current clinical challenges in the diagnosis, prevention, and treatment of HFpEF. This chapter gives a literature overview of the current diagnosis, pathological understanding of HFpEF, and rodent models for HFpEF and introduces potential therapeutic options for patients with HFpEF. Chapter 2 describes the rationale and aims of thesis.

In chapter 3, we investigated the effects of the two most common anaesthetics, ketamine/xylazine and isoflurane, on cardiac function, especially diastolic dysfunction, in HFpEF-diseased obese ZSF1 rats. In echocardiography, ketamine/xylazine was able to demonstrate diastolic dysfunction in obese ZSF1 rats. In contrast to ketamine/xylazine, isoflurane impeded the reliable measurement of diastolic function, resulting in underdiagnosis of diastolic dysfunction in HFpEF-diseased obese ZSF1 rats. Well-considered evaluation of anaesthetics usage during the echocardiographical assessment of diastolic function is therefore required both in animal models and patients. 
In chapter 4, we showed that active cardiac capillary regression caused by the loss of the mural support cells, called pericytes, is an early event in the development of HFpEF, leading to microvascular rarefaction in established HFpEF. Capillary regression coincided with endothelial activation and junctional remodelling and occurred before the development of other key pathological processes, including diastolic dysfunction, cardiac fibrosis, and cardiac and systemic inflammation. The reduced pericyte density at this early stage in vivo might be explained by an increased vulnerability of pericytes to metabolic stressors, including hyperglycaemia, hyperlipidaemia, and oxidative stress, compared to endothelial cells, as shown in vitro. Thus, targeting the microvasculature, especially stabilising pericytes, could be a potential new therapy for HFpEF.

In chapter 5, we demonstrated that the currently used anti-diabetic drug linagliptin prevents metabolic risk-induced cardiac stiffening by reducing the cardiomyocyte passive stiffness, the earliest manifestation of diastolic dysfunction. This was mediated by prevention of direct cleavage of the giant spring titin, which is responsible for cardiac relaxation. In addition, the indirect modulation of titin phosphorylation, titin isoform switching, and reduced cardiac fibrosis by linagliptin resulted in a reduced passive stiffness. Thus, reducing cardiomyocyte stiffness by administrating linagliptin could prevent the development of metabolic risk-induced diastolic dysfunction in patients.

To conclude, in chapter $\mathbf{6}$, we discuss the impact of the findings described in this thesis on the diagnosis and (early) pathophysiological understanding of HFpEF and development of novel preventive and therapeutic options in patients with HFpEF. Furthermore, we discuss that the development of novel animal models mimicking human pathophysiology are crucial for the development of early diagnostic markers and effective prevention and therapeutic strategies. 


\section{Nederlandse Samenvatting}

Meer dan de helft van de patiënten met hartfalen (HF) lijdt aan hartfalen met een behouden ejectiefractie (ejectiefractie >50\%), ook wel HFpEF genoemd. HFpEF is een complex cardiovasculair syndroom dat gekenmerkt wordt door diastolische dysfunctie en verstijving, fibrosis, ontsteking en hypertrofie van het hart. Veroudering en de toegenomen incidentie van veel voorkomende comorbiditeiten, zoals type 2 diabetes mellitus, hypertensie en obesitas, leiden tot een drastische toename van de prevalentie van HFpEF. Echter zijn er momenteel geen behandelingen voor HFpEF beschikbaar, doordat de onderliggende pathologie niet gekend is, de patiëntenpopulatie zeer heterogeen is en patiënten inadequaat gediagnosticeerd worden. In deze thesis onderzochten wij daarom het verloop van de ontwikkeling van HFpEF in een rat model dat de humane ziekte nabootst, de obese ZSF1 rat, om zo vroege ziekteverschijnselen te ontdekken. Dit onderzoek zal de risicostratificatie en de ontwikkeling van preventie- en behandelstrategieën vergemakkelijken.

Hoofdstuk 1 introduceert de huidige klinische uitdagingen voor de diagnose, preventie en behandeling van HFpEF. Dit hoofdstuk geeft een literatuuroverzicht over de huidige diagnose, ziekteontwikkeling in HFpEF en diermodellen voor HFpEF. Daarnaast worden potentiële behandelingen voorgesteld voor HFpEF patiënten. Hoofdstuk 2 beschrijft de rationale en de doelstellingen van deze thesis.

In hoofdstuk 3 hebben wij onderzocht wat de effecten van de twee meest gebruikte anesthetica (ketamine/xylazine en isofluraan) zijn op de hartfunctie, specifiek de diastolische functie, in obese ZSF1 ratten die lijden aan HFpEF. In obese ZSF1 ratten die geanestheseerd waren met ketamine/xylazine konden wij met behulp van echocardiografie diastolische dysfunctie diagnosticeren. Echter wanneer isofluraan als anestheticum werd gebruikt kon er met behulp van echocardiografie geen betrouwbare opname van de diastolische functie worden gemaakt. 
Dit resulteerde in onderdiagnose van diastolische dysfunctie in obese ZSF1 ratten die lijden aan HFpEF. Dit toont aan dat er bij echocardiografie een goed overwogen evaluatie van het type anestheticum vereist is voor het diagnosticeren van diastolische dysfunctie in zowel diermodellen als patiënten.

In hoofdstuk 4 toonden wij dat actieve regressie van de capillairen in het hart een vroeg verschijnsel is in de ontwikkeling van HFpEF. Deze actieve capillaire regressie werd veroorzaakt door het verlies van de ondersteunende cellen in de vaatwand, ook wel pericyten genoemd, en resulteerde in capillaire rarefactie nog voordat er klinische symptomen van HFpEF zichtbaar waren. Capillaire regressie ging tezamen met endotheel activatie en reorganisatie van endotheelcel junctie eiwitten, maar vond plaats voor de ontwikkeling van andere belangrijke pathologische processen (systemische ontsteking, diastolische dysfunctie en fibrose en ontsteking in het hart). De verminderde dichtheid van pericyten in dit vroeg stadium in vivo kan potentieel worden verklaard door het feit dat in vitro pericyten gevoeliger waren voor metabole stress factoren (hyperglycemie, hyperlipidemie en oxidatieve stress) in vergelijking met endotheelcellen. Therapieën die een positief effect hebben op de microvasculatuur door de pericyten te stabiliseren zouden mogelijk de ontwikkeling van HFpEF kunnen vertragen of zouden zelfs HFpEF kunnen genezen.

In hoofdstuk 5 toonden wij aan dat het medicijn dat tegenwoordig wordt gebruikt voor de behandeling van type 2 diabetes, linagliptin genaamd, de ontwikkeling van metabool risicogeïnduceerde verstijving van het hart voorkomt. Dit was het gevolg van het verhinderen van de ontwikkeling van de vroegste manifestatie van diastolische dysfunctie, ook wel toegenomen passieve stijfheid van hartcellen genoemd. Titine, het grootste eiwit in het lichaam, is verantwoordelijk voor de relaxatie van het hart. De verminderde passieve stijfheid van de hartcellen was het gevolg van de verhinderde splitsing van titine. Daarnaast resulteerde toegenomen fosforylering van titine, het switchen van de titine isovormen en verminderde 
fibrose in een afgenomen passieve stijfheid van de hartcellen. Linagliptin kan dus potentieel door middel van het verminderen van de stijfheid van hartcellen de ontwikkeling van diastolische dysfunctie voorkomen in patiënten met een verhoogd metabool risico.

Tot slot wordt in hoofdstuk 6 de impact van de bevindingen van deze thesis op de diagnose, het begrip van de ziekteontwikkeling en de ontwikkeling van nieuwe preventie- en behandelingsmethoden besproken. Daarnaast wordt de urgentie voor het ontwikkelen van nieuwe diermodellen die de ziekteontwikkeling in HFpEF patiënten nabootsen besproken. 